\title{
Sterile Cell Culture Product Processing
}

National Cancer Institute

\section{Source}

National Cancer Institute. Sterile Cell Culture Product Processing. NCI Thesaurus. Code C112946.

Cell culture techniques done under aseptic conditions. 